\title{
Identification of lactose ureide, a urea derivative of lactose, in milk and milk products
}

\author{
K. Suyama, ${ }^{\star 1}$ A. Sasaki, $\uparrow$ T. Oritani, $\uparrow$ and A. Hosonoł \\ *Department of Molecular Biology, Center for Translational and Advanced Research, Graduate School of Medicine, Tohoku University, \\ Sendai 980-8575, Japan \\ †Faculty of Agriculture, Tohoku University, Sendai 981-8555, Japan \\ łJapan Dairy Technical Association, Tokyo 102-0073, Japan
}

\section{ABSTRACT}

With the widespread consumption of milk, the complete characterization of the constituents of milk and milk products is important in terms of functionality and safety. In this study, a novel nonreducing carbohydrate was separated from powdered skim milk and was identified using electron spray ionization-mass spectrometry $\left(m / z\right.$ 385.1[M $\left.\left.+\mathrm{H}^{+}\right]\right),{ }^{1} \mathrm{H},{ }^{13} \mathrm{C},{ }^{1} \mathrm{H}^{1} \mathrm{H}$-correlation spectroscopy, and heteronuclear single quantum-nuclear magnetic resonance spectra. The carbohydrate was identified as a lactose derivative of urea, $\mathrm{N}$-carbamoyl$o$ - $\beta$-D-galactopyranosyl-(1-4)-D-glucopyranosylamine (lactose ureide, LU). For the HPLC analysis of LU in milk and milk products, benzoylated LU, hepta-obenzoyl lactose ureide (melting point $137-139^{\circ} \mathrm{C} ; \mathrm{m} / \mathrm{z}$ $1,113\left[\mathrm{M}+\mathrm{H}^{+}\right]$; wavelength of maximum absorption, $\lambda_{\max }, 229 \mathrm{~nm}$; molar extinction coefficient, $\varepsilon, 8.1037 \times$ $10^{7}$ ), was used as a standard. The crude nonreducing carbohydrate fraction from raw milk, thermally processed milk, and milk products such as powdered milks were directly benzoylated and subjected to HPLC analysis using an octadecylsilyl column to determine the quantity of LU. The content of LU in $10 \%$ solutions of powdered skim milk and powdered infant formula (5.0 \pm 1.1 and $4.9 \pm 1.5 \mathrm{mg} / \mathrm{L}$, respectively) were almost 3 -fold higher than that of UHT milk $(1.6 \pm 0.5 \mathrm{mg} / \mathrm{L})$ and higher than that of low-temperature, long-timeprocessed (pasteurized at $65^{\circ} \mathrm{C}$ for $\left.30 \mathrm{~min}\right)$ milk $(1.2$ $\pm 0.3 \mathrm{mg} / \mathrm{L})$ and the fresh raw milk sample $(0.3 \pm 0.1$ $\mathrm{mg} / \mathrm{L})$. A time-course of the $\mathrm{LU}$ content in raw milk during heating at $110^{\circ} \mathrm{C}$ revealed that $\mathrm{LU}$ increased with time. From these results, it is likely that LU is formed by the Maillard-type reaction between the lactose and urea in milk and milk products. Because the concentration of LU in milk increased with the degree of processing heat treatment, it could serve as an indicator of the thermal deterioration of milk. Although it

Received July 7, 2011.

Accepted August 16, 2011.

${ }^{1}$ Corresponding author: kz-suyama@med.tohoku.ac.jp is known that the human intestine is unable to digest $\mathrm{LU}$, the gastrointestinal bacteria in human subjects are able to digest and utilize urea nitrogen in formation of essential amino acids that are available to the host human. These findings suggest that LU in milk might have a functional role in human health.

Key words: lactose ureide, lactose, urea, milk

\section{INTRODUCTION}

Nonreducing carbohydrates comprise the most abundant group of natural compounds. Although the composition of milk has been extensively characterized, no reports have been found of the identification of a nonreducing sugar in any type of milk or associated milk product. This study aimed first to separate novel nonreducing sugars from bovine milk and determine their detailed structure. Our group previously reported the development of an effective method for the separation of nonreducing sugars (Suyama et al., 1989). This approach was applied to powdered skim milk, and the subsequent structural identifications of isolated nonreducing sugars were carried out. One unique sugar was separated from skim milk and identified as $N$-carbamoyl$o$ - $\beta$-D-galactopyranosyl-(1-4)-D-glucopyranosylamine, also known as lactose ureide (LU), a urea derivative of lactose. No reports were found of LU being identified in any type of milk or milk products, so qualitative and quantitative analyses of LU in various types of sterilized milks and powdered milk products were performed by HPLC.

Markedly different patterns of bacterial growth have been observed between LU and lactose when these were supplied as a carbon source during an in vitro study (Merry et al., 1982a,b). In ruminant nutrition, $\mathrm{LU}$ is potentially beneficial both in terms of reduction of toxicity of the NPN source and its efficiency of use for rumen microbial synthesis (Merry et al., 1982a,b,c). The results suggest that LU is a source of NPN with a built-in supply of readily available carbohydrate to ruminants such as bovine. Recent studies on humans have also shown that LU is completely resistant to the 
body's digestive process (Jackson et al., 1999). Although the action of lactase may release galactose and glucose ureide from LU (Ruemmele et al., 1997), when LU is taken orally, LU is hydrolyzed by the gastrointestinal bacteria in normal human subjects and urea nitrogen of LU can be utilized in the formation of essential amino acids that are available to the host human (Ruemmele et al., 1997). These findings suggest that LU in milk might have a functional role in human health.

It is well recognized that thermal processing changes the composition of milk (Jones et al., 1998; Cataldi et al., 1999), and the Maillard reaction is the main cause of these changes. The Maillard reaction occurs between carbonyl groups, such as those present in reducing sugars, and the amino group of proteins. In milk, lactose represents the main reducing sugar involved in this reaction and it forms various products (Albala-Hurtado et al., 1999; Ferrer et al., 2000; Siciliano et al., 2000). The compounds formed by the Maillard reaction during the processing and sterilization of milk are used as an index of the degree of heat treatment. For example, lactulose is used as an index to distinguish between various types of milks. Moreover, furosine $[\varepsilon-N-(2-$ furoylmethyl-L-lysine)], which is generated by acid degradation of the Amadori rearrangement reaction products of the Schiff base between lactose and lysine residues of milk proteins, has also attracted attention as a potential indexing substance (Evangelisti et al., 1999; Morales and Jimenez-Perez, 2000; Ohta et al., 2002). Lactose ureide is likely formed by a Maillardtype reaction between lactose and urea, and it could serve as an indicator of the thermal deterioration of milk. As mentioned above, milk components are fundamentally important for human health. In this study, we attempted to quantify the novel nonreducing sugar LU in raw milk, powdered infant formula, skim milk, and heated milk. We also investigated the relationships between the thermal process and LU formation.

\section{MATERIALS AND METHODS}

\section{Samples}

The milk samples used in this study were 5 powdered infant formulas (commercially available from Japan; 2 lots each of A and B brands, and 1 lot of $\mathrm{C}$ brand), 5 different lots of skim milk powder (D brand, Japan), and 5 samples of commercially available UHT-processed (pasteurized at $120^{\circ} \mathrm{C}$ for 2 s) milk (2 different lots of $\mathrm{E}$ and $\mathrm{F}$ brands and $1 \mathrm{G}$ brand), and 3 commercially available samples of low-temperature long-time (LTLT)-processed (pasteurized at $65^{\circ} \mathrm{C}$ for $30 \mathrm{~min}$ ) milk. Three different samples of raw milk were freshly obtained from 3 healthy Holstein cows from the Tohoku
University stock farm. Heated raw milk samples were prepared by heating at $110^{\circ} \mathrm{C}$ for $30 \mathrm{~min}$ and fresh raw milk samples of fresh raw milk by heating for $1 \mathrm{~h}$.

\section{Materials}

Silica Gel 60 (particle size 63-200 $\mu \mathrm{m}$ ) for column chromatography and thin-layer chromatography (TLC) plates (Silica Gel 60 precoated on a $20 \times 20 \mathrm{~cm}$ aluminum sheet) were purchased from Merck (Darmstadt, Germany). The Sep-Pak silica cartridge column ( $5 \mathrm{~mL}$ ) was purchased from Waters (Milford, MA). Deuterium oxide $(99.97 \%)$ and deuterated chloroform $\left(\mathbf{C D C l}_{3}\right.$; 99.8\% deuterium) were purchased from Euriso-Top (Gif-Sur-Yvette, France). All other chemicals were of specially prepared reagent grade and were obtained from Nacalai Tesque (Kyoto, Japan).

\section{Instruments}

Electrospray ionization mass spectrometry (ESIMS) was performed using a Finnigan MAT TSQ700 instrument (Thermo Scientific, Franklin, MA). Firstatom bombardment mass spectrometry was performed using a Jeol Mstation JMS-700 instrument (Jeol, Tokyo, Japan). For this analysis, sample in m-nitrobenzyl alcohol was loaded on the stainless steel target, which was then bombarded with xenon atoms. ${ }^{1} \mathrm{H}$ and ${ }^{13} \mathrm{C}$-nuclear magnetic resonance (NMR) spectra were recorded in $\mathrm{D}_{2} \mathrm{O}$ or $\mathrm{CDCl}_{3}$ at $600 \mathrm{MHz}$ with a Unity INOVA 600 spectrometer (Varian, Palo Alto, CA) operated at $50^{\circ} \mathrm{C}$.

\section{Preparation of Nonreducing Carbohydrate Fraction from Skim Milk}

Skim milk powder (200 g) was dissolved in $500 \mathrm{~mL}$ of hot water $\left(60^{\circ} \mathrm{C}\right), 1 \mathrm{~L}$ of methanol was immediately added to the solution, and the mixture was maintained at $4^{\circ} \mathrm{C}$ overnight. The resulting precipitate, which consisted predominantly of amorphous proteins and lactose crystals, was removed by centrifugation at 28,000 $\times g$ for 20 min at $4^{\circ} \mathrm{C}$. The $\mathrm{H}_{2} \mathrm{O}$-methanol supernatant layer was concentrated using a rotary evaporator under reduced pressure to $500 \mathrm{~mL}$. The lactose in the concentrate was then crystallized by cooling at $4^{\circ} \mathrm{C}$ for $1 \mathrm{wk}$, and lactose crystal was separated followed by centrifugation at $28,000 \times g$ for $20 \mathrm{~min}$ at $4^{\circ} \mathrm{C}$. The aqueous layer, which consisted predominantly of carbohydrates, was used as the crude carbohydrate fraction for subsequent purification.

\section{Isolation of the Nonreducing Sugar Fraction}

To eliminate the remaining lactose in the crude carbohydrate fraction of skim milk, an aqueous layer was 
treated with aniline as described previously (Suyama et al., 1987). Briefly, the aniline reagent was prepared by mixing aniline with acetic acid at a ratio of 5:2 ( vol/ vol). An aqueous solution of the sample was mixed with an identical volume of aniline reagent and then heated at $85^{\circ} \mathrm{C}$ for $5 \mathrm{~h}$. After cooling the reaction mixture to room temperature, the deep brown amorphous polymer was separated from the aqueous solution by centrifugation at $28,000 \times g$ for $20 \mathrm{~min}$ at $4^{\circ} \mathrm{C}$. The remaining brown aqueous fraction was treated separately 3 times with diethyl ether and ethyl acetate. The nonreducing sugars and ketoses, which were shown in our previous report (Suyama et al., 1987) to be not reactive toward aniline, were thus present in the aqueous fraction. Carbohydrates were separated using silica gel column chromatography (20 mm internal diameter $\times 150 \mathrm{~mm}$ ), with a solvent system of (3:2:1:1 n-butanol:acetic acid:diethyl ether:water, by vol). Each fraction of carbohydrate was collected and the solvent was evaporated with a rotary evaporator until dryness. Unidentified carbohydrate corresponding to the LU was then crystallized (prism) from methanol and underwent structural analysis.

\section{TLC of Carbohydrates}

Thin-layer chromatography was performed using n-butanol:acetic acid:diethyl ether:water (3:2:1:1, by vol) as a solvent with 2 developments. Each spot was visualized by spraying a solution containing $2.0 \%$ diphenylamine, $2.0 \%$ aniline, and $22 \%$ phosphoric acid in acetone onto the plate, which was then heated at $120^{\circ} \mathrm{C}$ for $5 \mathrm{~min}$.

\section{Synthesis of LU}

Lactose ureide was synthesized by the method used for the synthesis of glucose ureide as described by Merry et al. (1982a). Briefly, equal weights (100 g) of lactose and urea were dissolved in $800 \mathrm{~mL}$ of distilled water, and then $20 \mathrm{~mL}$ of sulfuric acid $(4.5 \mathrm{M})$ was added under stirring. The resulting reaction mixture was maintained at $70^{\circ} \mathrm{C}$ for $5 \mathrm{~d}$ with shaking for 1 min twice daily. The resultant faintly colored greenish-yellow liquid was concentrated to approximately $200 \mathrm{~mL}$ under reduced pressure at $37^{\circ} \mathrm{C}$ using a rotary evaporator. Methanol $(300 \mathrm{~mL})$ was added to the thin syrup obtained and the mixture was kept at $4^{\circ} \mathrm{C}$ for $48 \mathrm{~h}$ to allow crystallization to occur. The obtained crystals were separated through filter paper (Toyo No. 2, Advantec, Tokyo, Japan) using a Buchner funnel, washed in $100 \mathrm{~mL}$ of methanol, and then refiltered. Recrystallization was carried out using methanol:water $(1: 2, \mathrm{vol} / \mathrm{vol})$ to yield $80 \mathrm{~g}$ of LU. The crystals were dried in vacuum desiccator over di- phosphorus pentoxide. The compound was charged on structural analysis.

\section{Synthesis of Hepta-o-Benzoyl LU}

Ten grams of dried LU was added to $800 \mathrm{~mL}$ of benzoylation reagent [benzoic anhydride $(50 \mathrm{mg} / \mathrm{mL})$ and 4-dimethylaminopyridine $(25 \mathrm{mg} / \mathrm{mL})$ in dry pyridine], mixed, and then incubated for $24 \mathrm{~h}$ at $37^{\circ} \mathrm{C}$. The reaction mixture was concentrated to approximately 300 $\mathrm{mL}$ under reduced pressure at $37^{\circ} \mathrm{C}$ using a rotary evaporator. Chloroform $(100 \mathrm{~mL})$ was then added and the resulting mixture was stirred for 10 min at room temperature. The chloroform fraction was separated and then washed with ice water, $3 \% \mathrm{HCl}$, and $3 \% \mathrm{NaHCO}_{3}$. The chloroform fraction was concentrated using a rotary evaporator under reduced pressure as described by Chaturvedi et al. (1997). The concentrate was charged onto a silica gel column for flash chromatography in hexane:ethyl acetate $(4: 1, \mathrm{vol} / \mathrm{vol})$. hepta- $o$-benzoyl LU was collected as a syrup, and then crystallized from methanol to afford plate, with a melting point of 137 to $139^{\circ} \mathrm{C}$. Nuclear magnetic resonance $\delta_{\mathrm{H}}\left(\mathrm{CDCl}_{3}\right): 4.60$ (doublet, d, J = 9.1 Hz, H1), 4.24 (d, J = 7.5 Hz, H1), 3.72 (doublet of doublet, dd, $\mathrm{J}=1.7,10.1 \mathrm{~Hz}, \mathrm{H} 6^{\prime}$ ), $3.71(\mathrm{~d}, \mathrm{~J}=3.9 \mathrm{~Hz}, \mathrm{H} 4), 3.58(\mathrm{dd}, \mathrm{J}=8.2,11.7 \mathrm{~Hz}$, $\mathrm{H} 6$ ), 3.75 (dd, J = 8.0, $10.1 \mathrm{~Hz}, \mathrm{H}^{\prime}$ ), $3.54(\mathrm{dd}, \mathrm{J}=4.1$, $11.7 \mathrm{~Hz}, \mathrm{H} 6), 3.50$ (dd, J = 4.1, 8.2 Hz, H5), 3.48 (t, J $\left.=8.9 \mathrm{~Hz}, \mathrm{H} 3^{\prime}\right), 3.44(\mathrm{dd}, \mathrm{J}=3.3,9.9 \mathrm{~Hz}, \mathrm{H} 3), 3.43(\mathrm{dd}$, $\left.\mathrm{J}=7.7,8.9 \mathrm{~Hz}, \mathrm{H} 4^{\prime}\right), 3.42(\mathrm{ddd}, \mathrm{J}=1.7,7.7,8.0 \mathrm{~Hz}$, $\left.\mathrm{H} 5^{\prime}\right), 3.34(\mathrm{dd}, \mathrm{J}=8.0,9.9 \mathrm{~Hz}, \mathrm{H} 2), 3.19(\mathrm{t}, \mathrm{J}=9.1 \mathrm{~Hz}$, $\mathrm{H} 2$ ). Fast atom bombardment mass spectra: $\mathrm{m} / \mathrm{z} 1,113$, $\mathrm{UV}\left(\mathrm{CH}_{3} \mathrm{CN}\right): \lambda \max (\varepsilon): 229 \mathrm{~nm}\left(4.572 \times 10^{7}\right)$.

\section{Preparation of Milk Samples for HPLC Analysis}

Methanol $(2 \mathrm{~mL})$ was added to $1 \mathrm{~mL}$ of each liquid milk sample and to $10 \%$ aqueous solutions of powdered infant formulas and skim milk powders. Each resulting solution was mixed by vortexing and then centrifuged at $1,500 \times g$ for $20 \mathrm{~min}$. Two milliliters of supernatant was treated by adding an aniline reagent (aniline:acetic acid, $5: 2$, vol/vol) and then heated at $85^{\circ} \mathrm{C}$ for $5 \mathrm{~h}$. After cooling the reaction mixture to room temperature, the solution was washed twice with $4 \mathrm{~mL}$ of diethyl ether. The aqueous layer was concentrated to dryness and then further dried over diphosphorus pentaoxide under reduced pressure. To each dried sample, $2 \mathrm{~mL}$ of benzoylation reagent [benzoic anhydride $(50 \mathrm{mg} / \mathrm{mL}$ ) and 4-demethylalaminopyridine $(25 \mathrm{mg} / \mathrm{mL})$ in dry pyridine] was added. After mixing, the sample solutions were incubated for $24 \mathrm{~h}$ at $37^{\circ} \mathrm{C}$, concentrated to dryness, and then dissolved in hexane:ethyl acetate (1:1, 
vol/vol). The resulting solution was run through a SepPak silica cartridge column that was previously wetted with acetonitrile $(5 \mathrm{~mL})$ and equilibrated with $5 \mathrm{~mL}$ of hexane:ethyl acetate $(1: 1, \mathrm{vol} / \mathrm{vol})$. After washing the cartridge with $10 \mathrm{~mL}$ of hexane, the benzoylated derivatives were eluted with $3 \mathrm{~mL}$ of ethyl acetate. The eluate was dried under reduced pressure to dryness, and dissolved in $500 \mu \mathrm{L}$ of acetonitrile, and then equal volumes of the solution were charged on the HPLC.

\section{HPLC Analysis of Benzoylated Derivative of Carbohydrates}

The HPLC was performed with a reverse-phase system using a Mightysil RP-18 column $(4.6 \times 150 \mathrm{~mm}$; Kanto-kagaku, Japan). The HPLC system consisted of an L-6020 pump (Hitachi, Japan), SPD-6AV UVvisible spectrophotometric detector (Shimadzu, Tokyo, Japan), and a C-R5A Chromatopac Data Station (Shimadzu). The optical density was monitored at $229 \mathrm{~nm}$. An acetonitrile:water $(65: 35, \mathrm{vol} / \mathrm{vol})$ solvent system at a flow rate of $1.0 \mathrm{~mL} / \mathrm{min}$ was used. All chromatographic operations were performed at room temperature. Quantitative analysis of LU was performed using a standard curve generated with known concentrations of synthesized hepta-o-benzoyl LU.

\section{Statistical Analysis}

One-way ANOVA was used for statistical analysis. The results are presented as means \pm standard deviations.

\section{RESULTS}

The carbohydrate fraction of skim milk powder was treated with aniline reagent and subjected to TLC. The TLC showed 2 main spots with retention factor (Rf) values of 0.45 and 0.35 , respectively, as shown in Figure 1. Because each of these spots represented an individual carbohydrate, they were purified by column chromatography and subjected to further analysis. The compound having an Rf of 0.45 was identified as lacturose because it showed an identical Rf value (Figure 1) and ${ }^{1} \mathrm{H}-\mathrm{NMR}$ spectrum (data not shown) to a lacturose standard.

The purified carbohydrate corresponding to the spot with $\mathrm{Rf}$ of 0.35 was analyzed by positive ion ESI-MS, which gave a molecular ion peak $[\mathrm{M}+\mathrm{H}]^{+}$at $m / z$ $(385.1),[\mathrm{M}+\mathrm{Na}]^{+}(407.0)$, and $[\mathrm{M}+\mathrm{K}]^{+}(423.1)$ as shown in Figure 2. Although not shown, the negative ion ESI-MS resulted in a molecular ion peak corresponding to $[\mathrm{M}-\mathrm{H}]^{-}$at $m / z(383.1)$ and $[\mathrm{M}+\mathrm{Cl}]^{-}(419.0)$. The purified carbohydrate was next subjected to ${ }^{1} \mathrm{H}-\mathrm{NMR}$ analysis and the result is shown in Figure 3. From the obtained spectrum, the coupling constant of H-4 signals $(3.9 \mathrm{~Hz})$ supported the presence of a galactose moiety due to axial-equatorial interaction between $\mathrm{H}-3$ and $\mathrm{H}-4$ protons, and the coupling constant of $\mathrm{H}-4^{\prime}$ signals (8.9 $\mathrm{Hz}$ ) supported the presence of a glucose residue due to axial-axial interaction between $\mathrm{H}-3^{\prime}$ and $\mathrm{H}-4^{\prime}$ protons. An $\alpha$-anomeric proton was not observed in the spectrum, and a $\alpha$-anomeric proton at the glucose residue observed at $4.81 \mathrm{ppm}$ was highly deshielded compared with that at the glucose residue of lactose $(4.65 \mathrm{ppm})$.

The ${ }^{1} \mathrm{H}$ and ${ }^{13} \mathrm{C}-\mathrm{NMR}$ signals were assigned after ${ }^{1} \mathrm{H}-{ }^{1} \mathrm{H}$ correlation spectroscopy (COSY), hetero-nuclear single quantum coherence (HSQC), and hetero-nuclear multiple-bond connectivity (HMBC) analysis as follows. The nonreducing sugar fraction: ${ }^{1} \mathrm{H}-\mathrm{NMR} \delta_{\mathrm{H}}(600$ $\left.\mathrm{MHz}, \mathrm{D}_{2} \mathrm{O}\right): 4.81\left(\mathrm{~d}, 1 \mathrm{H}, \mathrm{J}_{1,2} 9.1 \mathrm{~Hz}, \mathrm{H}_{-1} \mathbf{1}^{\prime}, 4.45(\mathrm{~d}, 1 \mathrm{H}\right.$,

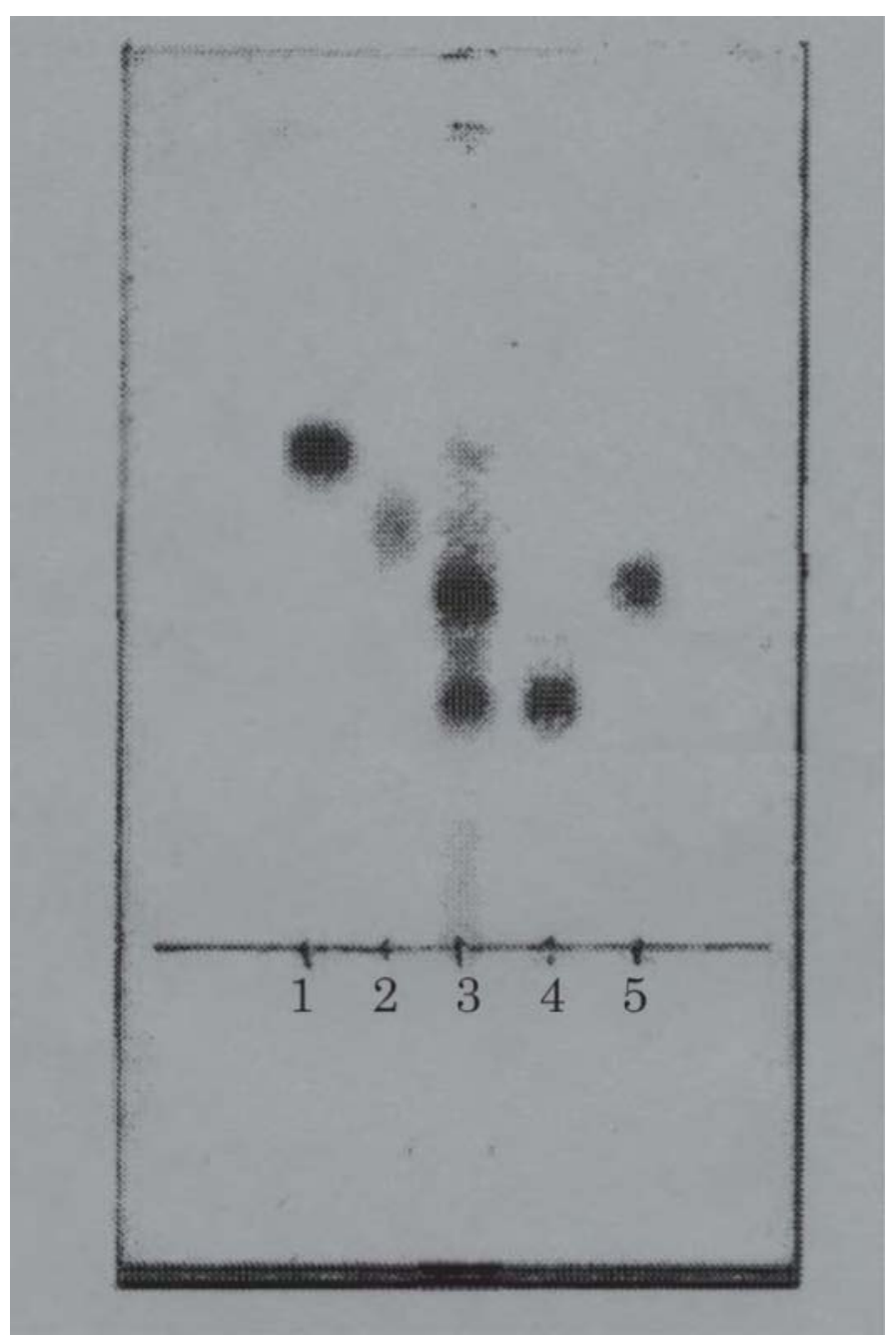

Figure 1. Thin-layer chromatography of the nonreducing carbohydrate fraction of separated from powdered skim milk. $1=$ glucose, 2 = galactose, $3=$ nonreducing carbohydrate fraction, $4=$ lacturose, 5 $=$ lactose ureide. 


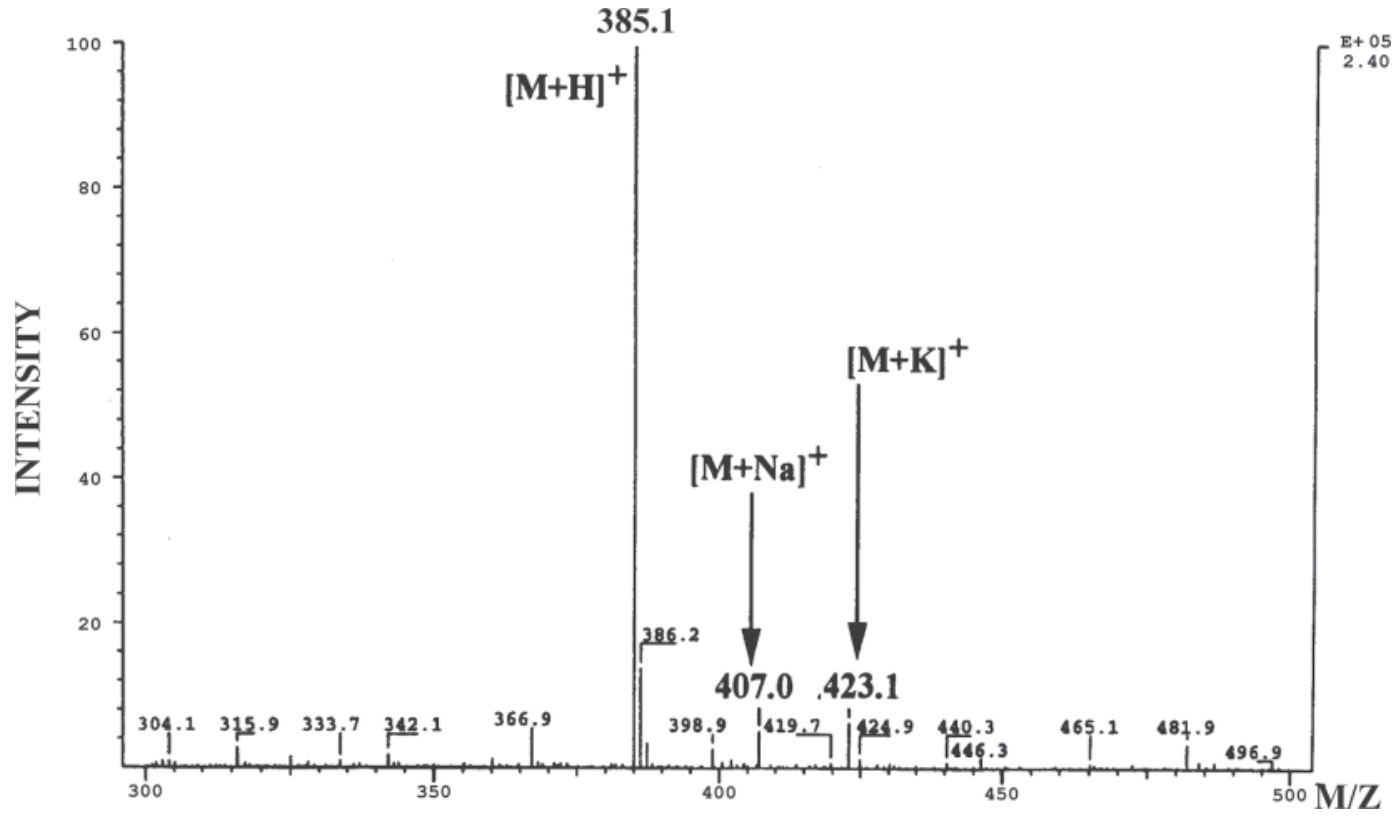

Figure 2. Positive ion electron spray ionization mass spectrometry of the compound purified from nonreducing carbohydrate fraction of skim milk powder sample.
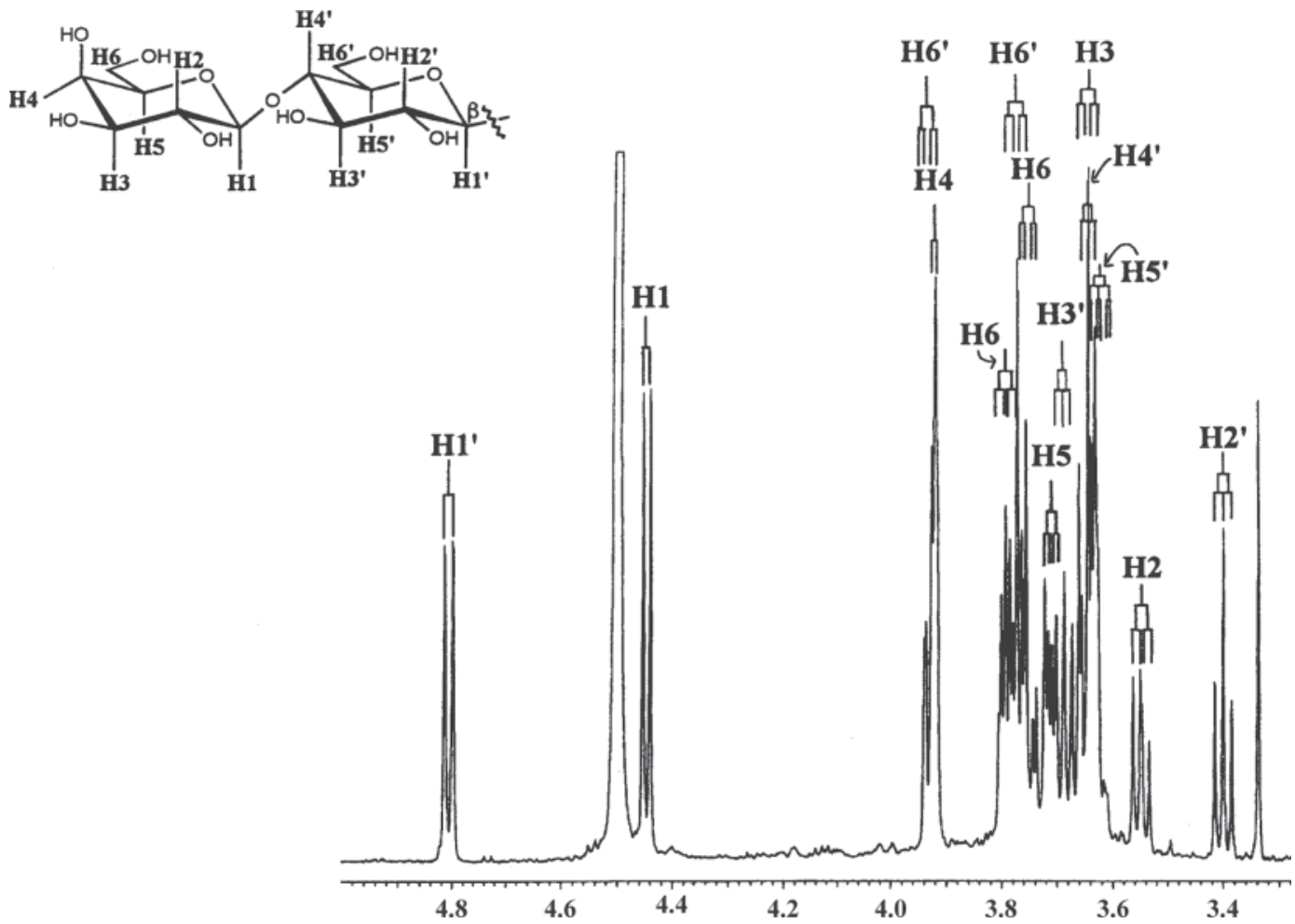

Figure 3. ${ }^{1} \mathrm{H}-$ Nuclear magnetic resonance spectrum of the compound purified from nonreducing carbohydrate fraction of skim milk powder sample. The structure of lactose ureide and assignment results are shown (inset). 


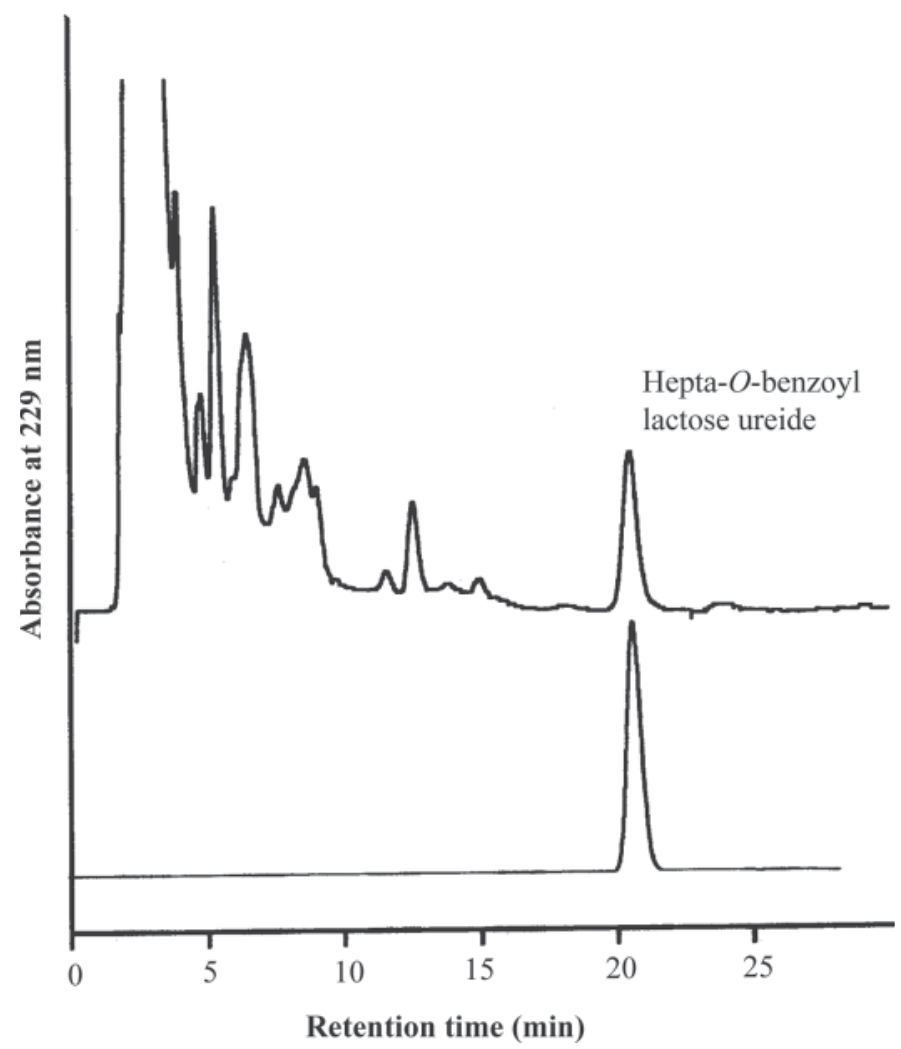

Figure 4. High-performance liquid chromatograms of the hepta-obenzoyl lactose ureide standard and a benzoylated sample of commercial milk. The synthesized benzoylated hepta-o-benzoyl lactose ureide standard (bottom) was eluted from the HPLC column after 21 min at room temperature and was detected by measuring the absorbance at $229 \mathrm{~nm}$. Benzoylated lactose ureide was observed in a commercial milk sample (top).

$\left.\mathrm{J}_{1,2} 7.5 \mathrm{~Hz}, \mathrm{H}-1\right), 3.93$ (dd, 1H, $\mathrm{J}_{6,6} 10.1 \mathrm{~Hz}, \mathrm{~J}_{5,6}, 1.7 \mathrm{~Hz}$, H-6'), 3.92 (d, 1H, J $3.43 .9 \mathrm{~Hz}, \mathrm{H}-4), 3.79$ (dd, 1H, $\mathrm{J}_{6,6}$ $11.7 \mathrm{~Hz}, \mathrm{~J}_{5,6} 8.2 \mathrm{~Hz}, \mathrm{H}-6$ ), 3.78 (dd, 1H, J $\mathrm{J}_{6,6} 10.1 \mathrm{~Hz}$, $\left.\mathrm{J}_{5,6} 8.0 \mathrm{~Hz}, \mathrm{H}-6^{\prime}\right), 3.75$ (dd, 1H, $\mathrm{J}_{6,6} 11.7 \mathrm{~Hz}, \mathrm{~J}_{5,6} 4.1 \mathrm{~Hz}$, $\mathrm{H}-6), 3.71\left(\mathrm{dd}, 1 \mathrm{H}, \mathrm{J}_{5,6} 8.2 \mathrm{~Hz}, \mathrm{~J}_{5,6} 4.1 \mathrm{~Hz}, \mathrm{H}-5\right), 3.69$ $\left(\mathrm{dd}, 1 \mathrm{H}, \mathrm{J}_{3.4} 8.9 \mathrm{~Hz}, \mathrm{~J}_{2.3} 8.9 \mathrm{~Hz}, \mathrm{H}-3^{\prime}\right), 3.65\left(\mathrm{dd}, 1 \mathrm{H}, \mathrm{J}_{3.4}\right.$ $3.3 \mathrm{~Hz}, \mathrm{H}-3$ ), 3.64 (dd, $1 \mathrm{H}, \mathrm{J}_{3.4} 8.9 \mathrm{~Hz}, \mathrm{~J}_{4.5} 7.7 \mathrm{~Hz}, \mathrm{H}-4^{\prime}$ ), 3.63 (ddd, 1H, J $\mathrm{J}_{5,6} 8.0 \mathrm{~Hz}, \mathrm{~J}_{4,5} 7.7 \mathrm{~Hz}, \mathrm{~J}_{5,6} 1.7 \mathrm{~Hz}, \mathrm{H}-5^{\prime}$ ), $3.55\left(\mathrm{dd}, 1 \mathrm{H}, \mathrm{J}_{2.3} 9.9 \mathrm{~Hz}, \mathrm{~J}_{1,2} 8.0 \mathrm{~Hz}, \mathrm{H}-2\right), 3.40$ (dd, $\left.1 \mathrm{H}, \mathrm{J}_{1,2} 9.1 \mathrm{~Hz}, \mathrm{~J}_{2,3} 9.1 \mathrm{~Hz}, \mathrm{H}-2^{\prime}\right) .{ }^{13} \mathrm{C}-\mathrm{Nuclear}$ magnetic resonance signals were assigned after HSQC as follows: $\delta_{\mathrm{C}}\left(600 \mathrm{MHz}, \mathrm{D}_{2} \mathrm{O}, 50^{\circ} \mathrm{C}\right): 160.67(\mathrm{C}=\mathrm{O}), 103.00(\mathrm{C} 1)$, 80.97 (C1'), 78.38 (C4'), 76.04 (C5'), 75.42 (C5), 75.24 (C3'), 72.70 (C3), $71.81\left(\mathrm{C} 2{ }^{\prime}\right), 71.07(\mathrm{C} 2), 68.68$ (C4), 61.08 (C6), $60.23\left(\mathrm{C} 6^{\prime}\right)$.

Figure 4 shows the typical HPLC chromatograms of hepta-o-benzoyl LU standard and a sample of commercial UHT milk benzoylated using $50 \mathrm{mg} / \mathrm{mL}$ benzoic anhydride and $25 \mathrm{mg} / \mathrm{mL}$ 4-dimethylaminopyridine in pyridine. Hepta-o-benzoyl LU was eluted as a single peak from the HPLC column at room temperature after $21 \mathrm{~min}$ and was clearly present in the milk sample. Hepta-o-benzoyl LU was also observed in all milk samples, including skim milk powder, powdered infant formulas, UHT milk, LTLT milk, and raw milk (Figure 5). The average LU content in each of the milk sample was determined using a standard curve, which revealed that a $10 \%$ solution of skim milk contained 5.0 $\pm 1.1 \mathrm{mg} / \mathrm{L}$, which was almost 3 -fold higher than that in UHT milk $(1.6 \pm 0.5 \mathrm{mg} / \mathrm{L})$. The samples of LTLT pasteurized milk contained a much lower amount of $\mathrm{LU}$ $(1.2 \pm 0.3 \mathrm{mg} / \mathrm{L})$ than that of UHT milks. A sample of raw milk had the lowest content of LU $(0.3 \pm 0.1$ $\mathrm{mg} / \mathrm{L})$.

To examine the effect of temperature on the formation of LU, the sample of raw milk was heated at $110^{\circ} \mathrm{C}$ for $30 \mathrm{~min}$ and $1 \mathrm{~h}$. As a result of this heat treatment, the amount of LU increased from 0.3 to $8.2 \pm 0.9 \mathrm{mg} / \mathrm{L}$ (at $1 \mathrm{~h}$ ) as shown in Figure 5.

\section{DISCUSSION}

In this study, the ESI-MS and NMR analysis of the nonreducing carbohydrate fraction from skim milk revealed the presence of a novel sugar in milk. The results of these analyses allowed us to assign the purified carbohydrate compound as LU, a urea derivative of lactose. To date, no reports exist of LU being found in any type of milk. From the structure determined for $\mathrm{LU}$, we speculate that it was formed by a Maillard-type condensation reaction between lactose and urea in milk.

The levels of LU in milk samples showed a relationship to the severity of processing and sterilization, with the highest concentrations being found in skim milk powder. Skim milk is manufactured by the centrifugal removal of cream from fresh milk, followed by condens-

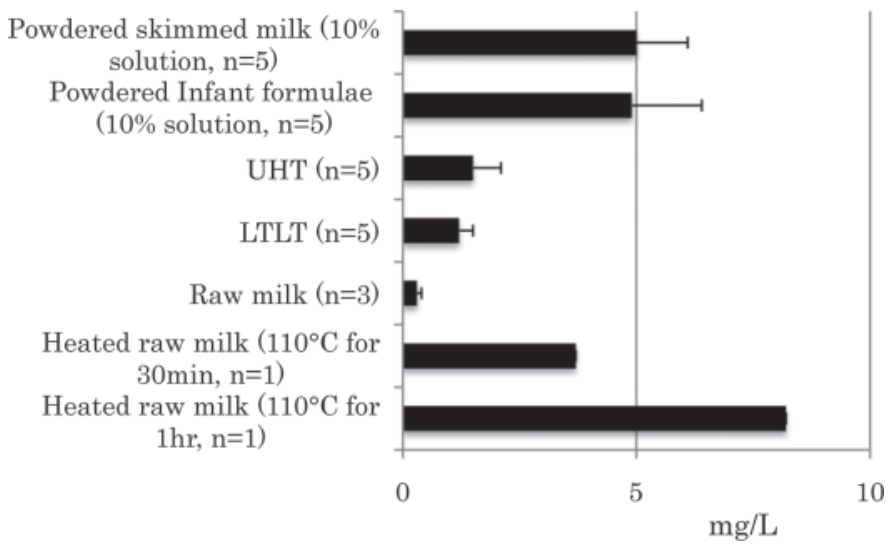

Figure 5. Lactose ureide (LU) concentration in several types of milk samples. The concentration of LU in each sample was determined using HPLC and a standard curve generated with a synthesized LU standard. 
ing by heating or spray drying to obtain skim milk powder. Although UHT milk is sterilized by either indirect or direct heating at 80 to $85^{\circ} \mathrm{C}$, it is further sterilized at 120 to $130^{\circ} \mathrm{C}$ for $2 \mathrm{~s}$ before packaging, whereas pasteurized (LTLT) milk is sterilized by heating for $65^{\circ} \mathrm{C}$ for 30 min. Such processing changes the composition of milk. The LU content in milk and milk products is likely the identical trend observed for substances used as the official index of milk quality, namely, lacturose and furosine. Therefore, the LU detected in this study represents another possible indicator of milk quality, although future research using a larger number of samples is required.

The levels of LU in milk may also be reflected in the urea content of milk (normal range: 10-14 mg/ $\mathrm{dL}$ ). Recently, MUN has been recognized as one tool to evaluate ration protein and energy status (Kauffman and St-Pierre, 2001; Jonker et al., 2002; Nousiainen et al., 2004; Wattiaux et al., 2005). The Feed Management 592 Practice Standard was adopted by the National Resources Conservation Service (NRCS, 2003) as another tool to assist with addressing resource concerns on livestock and poultry operations. Fed management can assist with reducing the import of nutrients to the farm and reduce the excretion of nutrients in manure. Milk processing plants and DHI can provide daily managers with MUN values in bulk milk and individual cow milk samples (Wattiaux et al., 2005). The MUN level is a useful tool that can allow dairy managers to monitor changes in the feeding and management of their herds (Nousiainen et al., 2004).

On the other hand, recent studies have demonstrated that LU is completely resistant to the body's digestive enzymes, although the action of lactase may release galactose and glucose ureide (Ruemmele et al., 1997) and can be used to obtain information on aspects of the handling material by the colonic microflora in normal human subjects (Jackson et al., 1999). Our results showed that the consumption of milk and milk products led to an increase in LU intake. Although it is known that the human intestine is unable to digest LU, the precise health effects of consuming LU in milk and milk products is unknown at this time.

\section{ACKNOWLEDGMENTS}

The study was supported by the Japan Racing \& Livestock Promotion Foundation (Tokyo, Japan).

\section{REFERENCES}

Albala-Hurtado, S., M. T. Veciana-Nogues, A. Marine-Font, and M. C. Vidal-Carou. 1999. Progress of browning reactions during storage of liquid infant milks. J. Agric. Food Chem. 47:4033-4037.
Cataldi, T. R. I., M. Angelotti, and S. A. Bufo. 1999. Method development for the quantitative determination of lacturose in heat-treated milks by HPAEC with pulsed amperometric detection. Anal. Chem. 71:4919-4925.

Chaturvedi, P., C. D. Warren, G. M. Ruiz-Palacis, L. K. Pickering, and D. S. Newburg. 1997. Milk oligosaccharide profiles by reserved phase HPLC of their perbenzoylted derivatives. Anal. Biochem. 251:89-97.

Evangelisti, F. J., C. Calcagno, S. Nardi, and P. Zunin. 1999. Deterioration of protein fraction by Maillard reaction in dietetic milks. J. Dairy Res. 66:237-243.

Ferrer, E., A. Alegria, G. Courtois, and R. Farré. 2000. High-performance liquid chromatographic determination of Maillard compounds in store-brand and name-brand ultra-high-temperature treated cow's milk. J. Chromatogr. A 881:599-606.

Jackson, A. A., R. Bundy, A. Hounslow, L. Murphy, and S. A. Wootton. 1999. Metabolism of lactose- $\left[{ }^{13} \mathrm{C}\right]$ ureide and lactose- $\left[{ }^{15} \mathrm{~N},{ }^{15} \mathrm{~N}\right]$ ureide in normal adults consuming a diet marginally adequate in protein. Clin. Sci. 97:547-555.

Jones, A. D., C. M. Tier, and J. P. G. Wilkins. 1998. Analysis of the Maillard reaction products of beta-lactoglobulin and lactose in skimmed milk powder by capillary electrophoresis and electrospray mass spectrometry. J. Chromatogr. A 822:147-154.

Jonker, J. S., R. A. Kohn, and J. High. 2002. Use of milk urea nitrogen to improve cow diets. J. Dairy Sci. 85:939-946.

Kauffman, A. J., and N. R. St-Pierre. 2001. The relationship of milk urea nitrogen excretion in Holstein and Jersey cows. J. Dairy Sci. 84:2284-2294.

Merry, R. J., R. H. Smith, and A. B. McAllan. 1982a. Glycosyl ureides in ruminant nutrition. 1. Preparation and estimation of lactosyl urea and other glycosyl ureides. Br. J. Nutr. 48:275-286.

Merry, R. J., R. H. Smith, and A. B. McAllan. 1982b. Glycosyl ureides in ruminant nutrition. 2 . In vitro studies on the metabolism of glycosyl ureides and their free component molecules in rumen contents. Br. J. Nutr. 48:287-304.

Merry, R. J., R. H. Smith, and A. B. McAllan. 1982c. Glycosyl ureides in ruminant nutrition. 3 . In vivo studies on the metabolism of glycosyl ureides and corresoonding mixtures of their free component molecules. Br. J. Nutr. 48:305-318.

Morales, F. J., and S. Jimenez-Perez. 2000. Effect of malondialdehyde on the determination of furosine in milk-based products. J. Agric. Food Chem. 48:680-684.

Nousiainen, J., K. J. Shingfield, and P. Huhtanen. 2004. Evaluation of milk urea nitrogen as a diagnostic of protein feeding. J. Dairy Sci. 87:386-398.

NRCS (Natural Resources Conservation Service). 2003. Natural Resources Conservation Service conservation practice standard. Feed management. Code 592. http://www.nrcs.usda.gov/Internet/ FSE_DOCUMENTS/nrcs143_026292.pdf.

Ohta, T., T. Yoshida, B. Kanzaki, A. Hosono, and K. Suyama. 2002. Quantitative determination of furosin in cow's milk constituted skim milk. Milchwissenschaft 57:70-73.

Ruemmele, F. M., W. E. Heins, K. M. Keller, and M. J. Lentze. 1997. Metabolism of glycosyl ureides by human intestinal brush border enzymes. Biochim. Biophys. Acta 1336:275-280.

Siciliano, R. B. Rega, A. Amoresano, and P. Pucci. 2000. Modern mass spectrometric methodologies in monitoring milk quality. Anal. Chem. 72:408-415.

Suyama, K., C. J. Hwang, M. Fujii, and S. Adachi. 1987. Isolation of ketose or non-reducing sugars from the sugar mixture containing aldose by aniline treatment. Anal. Biochem. 162:325-329.

Wattiaux, M. A., E. V. Nordheim, and P. Crump. 2005. Statistical evaluation of factors and interactions affecting Dairy Herd Improvement milk urea nitrogen values in commercial Midwest dairy herds. J. Dairy Sci. 88:3020-3035. 